\begin{tabular}{l} 
SCIENCE \& TECHNOLOGY \\
Journal homepage: http://www.pertanika.upm.edu.my/ \\
\hline PERTANIKA
\end{tabular}

\title{
Effects of Noise Pollution from Electric Backup Generators on the Operators' Health
}

\author{
Mahmmoud Ismail Mohammed ${ }^{1}$ and Muwafaq Ayesh Rabeea ${ }^{2 *}$ \\ ${ }^{1}$ Faculty of Science, University of Mosul, Mosul, 41002, Iraq \\ ${ }^{2}$ Faculty of Applied sciences, University Of Anbar, Anbar 31001, Iraq
}

\begin{abstract}
Noise is a harmful pollutant that leads to an unsanitary environment in urban areas. Electric backup generators, widely used in developing countries, have been one of the most common noise sources. This study identifies workers' public health in public electrical backup generators in Mosul City, Iraq. Workers' health was assessed by measuring blood parameters, including $\mathrm{Hb}$, RBCs, WBCs, PLT, and PCV. In addition, other biochemical parameters have been tested, such as; TP, ALB, F.B.S, Bilirubin, Blood Urea, and Cholesterol. General Urine Examination (GUE) was implemented for all samples. The results show a significant change in the blood samples studied compared to the control sample. Hb increased to $15.72 \pm 0.9$ and $16.12 \pm 0.74 \mathrm{~g} / \mathrm{dl}$, at noise levels 92.5 and $94.8 \mathrm{~dB}$, respectively, compared to the control group $(14.07 \pm 0.20 \mathrm{~g} / \mathrm{dl})$. RBCs and PLT increased with the high noise level, whereas TP shows a decrease of about $6.43 \pm 0.46$ and $6.75 \pm 0.14$ $\mathrm{g} / \mathrm{dl}$ at 92.5 and $94.8 \mathrm{~dB}$, respectively, compared to the control group. Similarly, F.B.S, blood urea, and total cholesterol were increasing compared to the control group. Depending on the results obtained, up to $30 \%$ of the workers tested have severe hearing troubles. This percentage was classified as acute Hypacusis (57\%), severe Hypacusis (40\%), and complete deafness (3\%). Therefore, public electrical backup generators, which were randomly distributed in the public areas of developing countries, are a source of noise pollution.
\end{abstract}

Keywords: Biochemical parameters, blood, generator, noise pollution

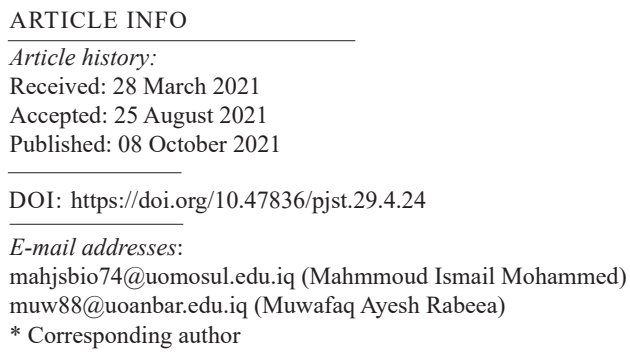

\section{INTRODUCTION}

People living in cities have risen over the last few decades, which has caused a number of health problems (Flies et al., 2019). In addition, the urban environment has become increasingly crowded, leading to a significant increase in pollution problems 
such as heat, noise, and air pollution. Therefore, these areas need continuous assessment and suggest technologies to reduce pollutants' exposure and density risks (Hussien et al., 2020; Mohammed et al., 2020; Paull et al., 2020).

Noise pollution is defined as a heterogeneous mixture of unwanted continuity sounds, usually due to industrial progress. This type of pollution is closely related to developed places, especially industrial places. Noise pollution has been placed in the second grade after water pollution in the cities. The technological development had resulted in many risks, despite the significant benefits provided by the urban technology to humankind, the advanced achievements that contributed to man's well-being, and the provision of his requirements. Still, there are great dangers and problems brought by this technology between its folds and contributed to causing great suffering for most of humanity. Noise is considered the most dangerous environmental pollutants and one type of physical environmental pollution due to its negative impact on psychological health. It also has physiological and social effects on humans. It is an invented pollution component that resulted from modernity's progress that depends on the use of machines, tools, means of transportation, conductors, and traffic signals that led to making significant changes in the sound environment (Adimalla et al., 2020; Dzhambov \& Dimitrova, 2016; Eduardo et al., 2015).

The World Health Organization (WHO) has announced that large cities' noise has harmful impacts on public health. These effects depend on the period and level of exposure of a person. WHO also reported that the acceptable limit for daily exposure to noise in residential areas is $55 \mathrm{~dB}$ (van Kempen et al., 2018; WHO, 2011). Noise at a certain sound level could cause damage to the ability of human hearing. When a person is subjected to a sound with an intensity of $85 \mathrm{~dB}$, he starts getting disturbed, and when the intensity of the sound becomes more than $90 \mathrm{~dB}$, the body organs start getting impacted. Continuous exposure to high sound levels, which caused further damage to the nerve cells in the inner ear, caused people to be deaf. The nerve cells are gradually eroded, and this issue has been known as neurodevelopmental hearing loss (Dzhambov et al., 2016; Sygna et al., 2014).

Noise is linked to a number of industries, such as textile and cement industries, as workers in such factories are exposed to the noise of more than $90-115 \mathrm{~dB}$, causing psychological and organic influences with temporary or permanent hearing loss (Jadaan et al., 2016; Vladimir \& Madalina, 2019). In addition, airports and highways in many countries have been recorded as a major noise source with a measuring sound between 56-65dB (Amoatey et al., 2020). Backup electric power generators are diesel-powered outdoor machines that supply temporary electrical power up to a specific voltage (Ashmore \& Dimitroulopoulou, 2009; Cuesta \& Cobo, 2000). During statutory power outages, most people depend on these types of generators to meet their commercial, industrial, and domestic electricity needs (Parvathi \& Gopalakrishnan, 2003). However, the noise caused 
by aerodynamic forces generated in such machines, which can reach $92.4 \mathrm{~dB}$ (Ibhadode et al., 2018), has a detrimental effect on the health of their operators. Therefore, the risk of exposure to noise from these sources, which may cause serious health problems for workers, must be assessed. Therefore, this study aimed to evaluate some blood parameters (biological and biochemical) for workers in public electrical backup generators. In addition, the workplace conditions have been assessed based on the slight hearing problems and the severe hearing problems resulting from this type of noise.

\section{MATERIAL AND METHODS}

Mosul is Iraq's second-largest city, with a population of around 1,800,000. It is located on the Tigris River in northern Iraq and was chosen as a case study to assess the effects of backup generator noise on the workers' health.

Eighty blood and urine samples were collected from operators of electrical backup generators in the study area. Men 35 and 40 years of age, with no social differences were targeted in this study. The collected samples were divided into two groups based on working time and noise levels. The first

Table 1

Classification of the number of samples collected

\begin{tabular}{lcc}
\hline \multirow{2}{*}{ Working } & \multicolumn{2}{c}{ Noise level } \\
\cline { 2 - 3 } & $94.8 \mathrm{~dB}$ & $92.5 \mathrm{~dB}$ \\
\hline 15 years & 15 & 15 \\
10 years & 15 & 15 \\
\hline
\end{tabular}
group consists of 60 samples, while the second group consists of 20 samples, as shown in Table 1.

The apparatus of sound level determination (Testo-815) was used to measure acoustic noise intensity level. In addition, the blood pressure was spatially checked using a Mercury Sphygmomanometer with a stethoscope (Yuyue) (Measurement range: 0-300mmHg and Sensitivity: $>2.25 \mathrm{mmHg}$ ).

The total protein amount was estimated using a ready-made analysis kit from the English company (Fortress/ UK). The method includes forming a coloured complex resulting from the interaction of the protein in the serum with a solution of basic copper potassium tartrate $\left(\mathrm{Cu}^{++}\right.$ions in the basic environment). It is known as the biorite detector to give a complex of purple colour whose intensity is proportional to the amount of protein, and the intensity of the solution is measured at the wavelength (550) nanometres (Arneson \& Brickell, 2007). The bilirubin concentration was estimated using ready-made Kit solutions. The method is based on bilirubin's interaction with the reagent Diazotized sulfalinic acid to form the Azobilirubin coloured compound. Dimethyl sulfoxide (DMSO) was added to estimate the total bilirubin (Arneson \& Brickell, 2007). The intensity was measured at a wavelength of $(550 \mathrm{~nm})$, proportional to the amount of bilirubin present in the blood serum. The ALB concentration was determined using the Bromocresol green method, in which a ready-made test kit was used from a company from (Biolab/France). It depends 
on the amount of albumin that binds with the reagent (3, 3, 5, 5-tetrabromocresol green) (Bromocresol green) BCG). The Albumin-BCG complex, which is green in colour, was measured at a wavelength of $630 \mathrm{~nm}$ (Arneson \& Brickell, 2007). The enzymatic method (Urease-Modified Berthelot Reaction) was used to quantify urea.

The method includes ready-made solutions from the French company (Biomerieux) containing the enzyme urease, which releases ammonia into the basic environment. Ammonia reacts with salicylate and hypochlorite to form 2, 2-dicarboxyndophenol, measured at a wavelength (580) nanometres by a spectrophotometer. The total serum cholesterol was determined using the Kit from Biolab/France. It is an enzymatic method based on converting cholesterol and cholesterol esters to the tincture of Quinoneimine. The analysis kit contains the enzyme cholesterol esterase, which works on the analysis of cholesterol in the blood serum into cholesterol and fatty acids and in the presence of oxygen and cholesterol oxidase, which works on free cholesterol due to the first reaction to cholesterol-4-en-3-one and hydrogen peroxide. The formed peroxide interacts with phenol and 4-amino antibairben in the presence of the peroxidase enzyme (peroxidase); a pink colour is formed resulting from the compound (Quinoneimine), and the intensity of the colour is directly proportional with the concentration of cholesterol in serum (Richmond, 1973). $10 \mathrm{ml}$ of urine was taken and placed in a test tube and was centrifuged for 3 minutes, then we kept the precipitate, which is placed on a glass slide, and a microscopic examination was performed on it to know the types of cells in the urine sample (Brunze, 2016).

A practical experiment was carried out using a random design. The obtained data were statistically analysed for each of the studied groups using the Duncan Multiple Range Test. The results were considered significant at the probability level $\leq 0.05$, using SAS's statistical program (Asker et al., 2021).

\section{RESULTS AND DISCUSSION}

Nowadays, the Iraqi environment can be considered a dangerous source of psychological and physiological impact on a person's health due to traffic chaos and the high intensity of electric generators. Noise is sonic waves that are transferred as electro-signals into the neurofibrils. The signals reach the cortex agitating its cells. Due to this agitation, such signals are passed to the Autonomic Nervous System, causing a malfunction of the Endocrine glands. Consequently, hormones of Adrenaline, Noradrenalin, Cortisol, and Growth are raised (Brink et al., 2019). The study area's noise level is $94.8 \mathrm{~dB}$ at some locations and $92.5 \mathrm{~dB}$ at other locations.

\section{The Noise Effect on the Hearing Sense}

The continuous directed exposure to certain force sound waves can reduce the ability to hear or cause the deaf. The high intensity of sound can cause damage to the nerve cells of the 
inner ear. Consequently, the nerve cells are gradually eroded, and the exposed person will be deaf. The noise in such sites is an influential impact on workers' health and performance. Psychological disturbances can be suffered as it distracts minds, and causes distress, dissatisfaction, increased nervousness, and sensitivity. The noise can also cause gradual damage in the eardrums, causing hard pain for the worker (Evandt et al., 2017; Gori et al., 2014; Oguntunde et al., 2019). The workers in the study area are suffering psychological tension due to the high noise. In addition, the immune system can be affected, leading to less protection to the body, including the middle ear causing buzzing and deafness. The impact of noise levels at $85,120-90$ and $<100 \mathrm{~dB}$ is caused by hearing loss (gradually), disturbances, and torturous pain in the eardrum, respectively (Esch et al., 2002; Sohrabi $\&$ Khreis, 2020). Researchers have found that among five workers working in high noise factories, one suffered from hearing loss. The sudden noise from severe explosions greater than $140 \mathrm{~dB}$ could also cause heart problems in heart patients (Maschke et al., 2002).

The generators' sites' noise intensity is measured to be 94.8 and $92.5 \mathrm{~dB}$, which lies at the level of $90-120 \mathrm{~dB}$. There are many effects noted depending on the noise intensity. Although $40 \%$ of the tested workers do not suffer from any impacts, $60 \%$ suffer from discomfort and slight disturbances, $30 \%$ suffer from severe hearing problems. Therefore, severe hearing problems have been shown that those with severe Hypacusis are $40 \%$, and an acute Hypacusis is $56.66 \%$, while complete deafness is $3.33 \%$, as in Figure 1 .

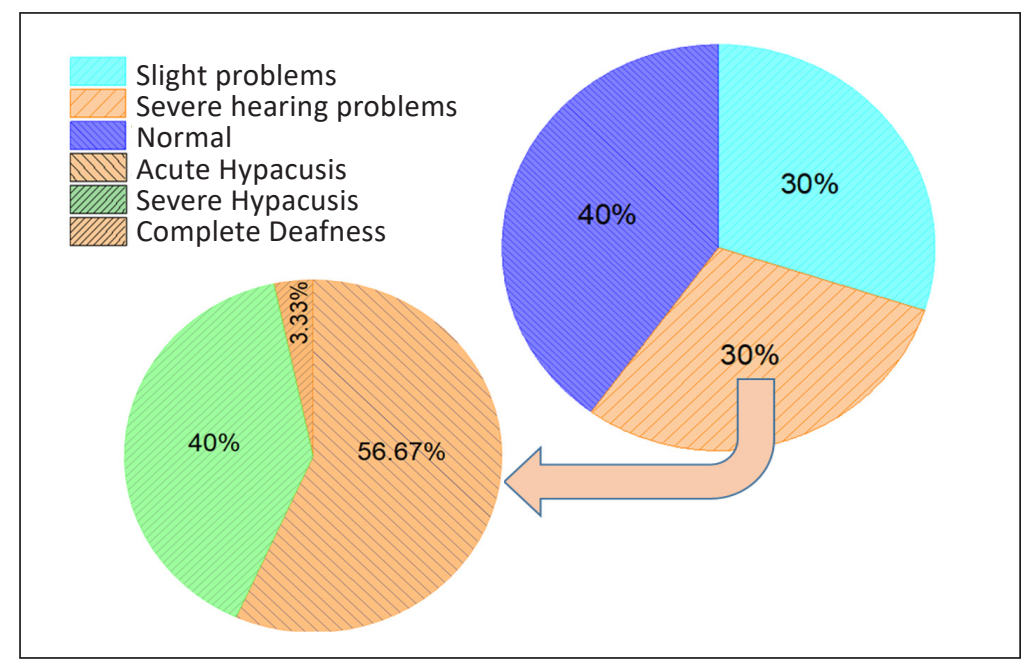

Figure 1. Percentage of people with hearing problems

\section{The Noise Effect on Blood Pressure and the Number of Heartbeats}

As shown in Figure 2, the operators working in such sites who suffer from high blood pressure were $40 \%$, and the rate of the heartbeats increased to $41 \%$. In the places where workers are exposed to high noises, the risk of heart disease has increased due to the 
increased tension that causes the release of Cortisol hormones, changes in the heart rate, and the widening of blood arteries. Consequently, there is a relationship between exposure to noise, high blood pressure, and heart function disorders. In addition, exposure to a highsudden noise could cause several physiological reactions within the human body, including adrenaline secretion, high blood pressure, increased heart beating rate, and breathing rate. Previous studies in this field found that workers exposed to noise ranging from 90-100dB per day suffer from high blood pressure (Dzhambov \& Dimitrova, 2017; Gori et al., 2014; van Kempen et al., 2018).

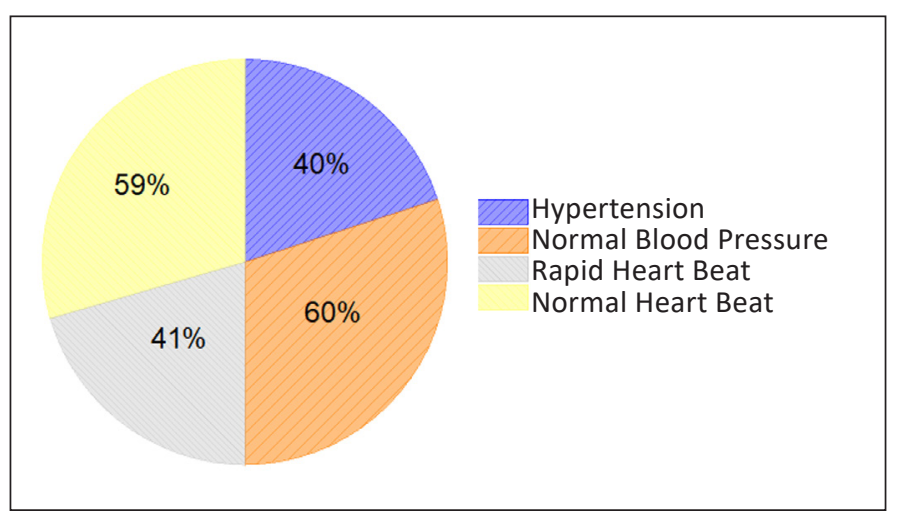

Figure 2. Impact of noise level on the heartbeat ( $\mathrm{mm} \mathrm{Hg}$ ) and hypertension (bpm)

\section{The Noise Effect on Hb, PCV and RBCs}

The results shown in Table 2 illustrated the concentrations of these variables changes in operators' blood according to the noise levels. For example, Hb highest concentration reaches $16.12 \pm 0.74$ according to the noise intensity of $94.8 \mathrm{~dB}$, while the lowest concentration of $\mathrm{Hb}$ was about $15.72 \pm 0.9$ at $92.5 \mathrm{~dB}$. In comparison, $\mathrm{PCV}$ ranges from 12.41 to $9.28 \%$ at different noise levels 94.8 and $92.5 \mathrm{~dB}$. On the other hand, RBCs reached $5.82 \pm 0.2$ and $5.67 \pm 0.28$ at 92.5 and $94.8 \mathrm{~dB}$, respectively. Besides the relationship between the noise level and the period work, the first group (15 years) showed the highest increase in $\mathrm{Hb}$ reached $13.67 \%$ compared to their values in the second group's blood (10 years), $0.7 \%$. Thus, the workers are exposed to noise at different levels, with increasing of the working periods affects the production of red blood cells, leading to changes in the blood components, which usually causes injury (Dongre et al., 2011; Le \& Hattingh, 1983).

\section{The Noise Effect on WBCs and PLT}

Table 2 shows that the number of WBCs and PLT showed a significant increase compared to the control groups. The highest values reach $8.38 \pm 1.5$ and $207.75 \pm 37.73$ at $94.8 \mathrm{~dB}$, while the lowest values reach $7.67 \pm 0.36$ and $165.75 \pm 16.37$ at $92.5 \mathrm{~dB}$, respectively. However, the control group's values were $(5.87 \pm 0.07)$ and $(137.5 \pm 3.23)$. Regarding the periods 
of exposure, the first group showed the highest values at $8.72 \pm 0.68$ and $211.75 \pm 36.34$ compared to the second group that reaches $7.3 \pm 0.7$ and $161.75 \pm 15.77$. Working with a high noise level of more than $70 \mathrm{~dB}$ for more than 8 hours per day affects the immune system's functions and thus increases WBCs, especially lymphatic ones. In addition, exposure to noise leads to changes in the blood components and, eventually, grows PLT that occurs in response to the effort caused by bulging blood cells (Brook \& Rajagopalan, 2009; Xiao et al., 2016).

Table 2

Impact of noise level and work-years on some blood components

\begin{tabular}{|c|c|c|c|c|c|c|}
\hline \multicolumn{2}{|c|}{ Parameter } & \multirow{2}{*}{$\begin{array}{c}\text { Noise level } \\
(94.8) \mathrm{dB}\end{array}$} & \multirow{2}{*}{$\begin{array}{c}\text { Noise level } \\
(92.5) \mathrm{dB}\end{array}$} & \multirow{2}{*}{$\begin{array}{c}\text { Working } \\
\text { years }(15) \\
16.65 \pm 0.75^{*}\end{array}$} & \multirow{2}{*}{$\begin{array}{c}\begin{array}{c}\text { Working } \\
\text { years }(10)\end{array} \\
14.4 \pm 0.6\end{array}$} & \multirow{2}{*}{$\begin{array}{c}\text { Control } \\
14.07 \pm 0.20^{*}\end{array}$} \\
\hline $\mathrm{Hb}$ & $\mathrm{Av} \pm \mathrm{St}$ error & & & & & \\
\hline $\mathrm{g} / \mathrm{dl}$ & Con $\%$ & 114.57 & 111.72 & 114.57 & 102.34 & 100 \\
\hline & Increase $\%$ & 14.57 & 11.72 & 14.57 & 2.34 & - \\
\hline \multirow[t]{3}{*}{ PCV \% } & $\mathrm{Av} \pm \mathrm{St}$ error & $48.45 \pm 2.22$ & $47.1 \pm 2.71$ & $49.42 \pm 2.27$ & $46.2 \pm 1.8$ & $43.1 \pm 0.21$ \\
\hline & Number\% & 112.41 & 109.28 & 114.66 & 107.19 & 100 \\
\hline & Increase $\%$ & 12.41 & 9.28 & 14.66 & 7.19 & - \\
\hline \multirow{3}{*}{$\begin{array}{l}\mathrm{RBCs} * 10^{6} / \\
\mathrm{mm}^{3}\end{array}$} & $\mathrm{Av} \pm \mathrm{St}$ error & $5.82 \pm 0.2 *$ & $5.67 \pm 0.28$ & $5.72 \pm 0.12 *$ & $5.16 \pm 0.4$ & $5.12 \pm 0.13^{*}$ \\
\hline & Number\% & 113.67 & 110.74 & 111.71 & 100.78 & 100 \\
\hline & Increase $\%$ & 13.67 & 10.74 & 11.71 & 0.78 & - \\
\hline \multirow{3}{*}{$\begin{array}{l}\text { WBC cells } \\
\text { per } \mu \mathrm{l}\end{array}$} & $\mathrm{Av} \pm \mathrm{St}$ error & $8.38 \pm 1.5^{*}$ & $7.67 \pm 0.36$ & $8.72 \pm 0.68^{*}$ & $7.3 \pm 0.7$ & $5.87 \pm 0.07 *$ \\
\hline & Number\% $\%$ & 142.75 & 130.66 & 148.55 & 124.36 & 100 \\
\hline & Increase $\%$ & 42.75 & 30.66 & 48.55 & 24.36 & - \\
\hline \multirow[t]{3}{*}{$\begin{array}{l}\mathrm{PLT}^{*} 10^{3} / \\
\mathrm{mm}^{3}\end{array}$} & $\mathrm{Av} \pm \mathrm{St}$ error & $\begin{array}{l}207.75 \\
\pm 37.73\end{array}$ & $\begin{array}{l}165.75 \\
\pm 16.37\end{array}$ & $\begin{array}{l}211.75 \\
\pm 36.34\end{array}$ & $\begin{array}{l}161.75 \\
\pm 15.77\end{array}$ & $\begin{array}{l}137.5 \\
\pm 3.22\end{array}$ \\
\hline & Number\% & 151.09 & 120.54 & 154 & 117.63 & 100 \\
\hline & Decrease $\%$ & 51.09 & 20.54 & 54 & 17.63 & - \\
\hline \multicolumn{2}{|c|}{ Bilirubin (mg/dl) } & $2.60 \pm 0.27$ & $2.27 \pm 0.16^{*}$ & $2.33 \pm 0.17 *$ & $2.37 \pm 0.19$ & $2.82 \pm 0.13^{*}$ \\
\hline \multicolumn{2}{|c|}{ Total Bilirubin (mg/dl) } & $1.11 \pm 0.27^{*}$ & $0.75 \pm 0.24$ & $1.07 \pm 0.42 *$ & $0.77 \pm 0.24$ & $0.73 \pm 0.01 *$ \\
\hline \multicolumn{2}{|c|}{ Conjugated Bilirubin (mg/dl) } & $0.59 \pm 0.15$ & $0.29 \pm 0.11$ & $0.50 \pm 0.12$ & $0.47 \pm 0.17$ & $0.17 \pm 0.04$ \\
\hline \multicolumn{2}{|c|}{ Unconjugated Bilirubin ( mg/dl) } & $0.40 \pm 0.20$ & $0.33 \pm 0.12$ & $0.55 \pm 0.18$ & $0.26 \pm 0.12$ & $0.24 \pm 0.06$ \\
\hline
\end{tabular}

\section{The Noise Effect on TP and Urea}

As shown in Table 3, the results revealed that TP concentrations decrease at different noise intensity levels compared to the control group. Urea concentrations showed an increase in serum of operators compared to the control group. The decrease in TP is $10.24 \%$ and $14.5 \%$, according to the noise levels 94.8 and $92.5 \mathrm{~dB}$, respectively. The highest urea concentration reached $55.1 \pm 0.65$ at $94.8 \mathrm{~dB}$ compared to the lowest concentration of $39.5 \pm 0.06$ at $92.5 \mathrm{~dB}$. Many environmental pollutants, including noise pollution, affect the formation of proteins in the liver, which is one of the liver's most critical functions. The amino acids are 
necessary for the formation of proteins, as any defect in this member's work will negatively affect the process of protein formation. Therefore, lower concentrations, which in turn will increase the level of urea as a final product of the amino acid metabolism (Allouche et al., 2011; Anetor et al., 2009; Oiamo et al., 2015).

\section{The Noise Effect on Concentrations of FBS, ALB, and Cholesterol}

According to the results, as shown in Table 3, it was found out that the glucose and albumin concentrations increased based on the noise intensity. The highest values reached 13.21 and $9.25 \%$ at a noise intensity of $94.8 \mathrm{~dB}$. Meanwhile, there was an increase in FBS and ALB concentrations, reaching 21.26 and $2.5 \%$, respectively. Regarding the effect periods work, the first group increased 45.11 and $8.75 \%$ compared to the second group, 14.39 and $3.5 \%$. In this field, previous studies have proved that noise exposure has many physiological reactions in humans, including an imbalance in the regulation of the composition of carbohydrates and the effects on the glucose levels in the blood. Therefore, patients with diabetes respond with more sensitivity than others to such noise pollutions (Roswall et al., 2018). At the same time, the cholesterol concentrations have reached the highest values, $16.8 \%$, at a noise level of $94.8 \mathrm{~dB}$, as shown in Table 3 . The noise levels at $92.5 \mathrm{~dB}$ showed an increase in cholesterol concentrations in the operators' serum, reaching 5.57\%. Concerning the work duration, the first group revealed an increased rate of $13.40 \%$ compared to the second group, $8.20 \%$. The noise pollution resulting from the noises of the various engines caused a high concentration of fat in the serum. This rise has a relationship with some factors, including exposure to noise of different levels and exposure to industrial pollutants (Yeatts et al., 2007).

\section{The Noise Effect on Concentrations of Total Bilirubin and Conjugated Bilirubin}

The results shown in Table 3 reported a clear rise in the concentrations of total bilirubin and conjugated bilirubin in the serum of operators exposed to different levels of severity of noise in comparison to the control group. The rise in bilirubin concentrations reached $1.11 \pm 0.27$ and $0.75 \pm 0.24$, according to the different noise intensities 94.8 and $92.5 \mathrm{~dB}$ compared to the control group $(0.73 \pm 0.01)$. Whereas the conjugated bilirubin reached the highest concentration of $0.59 \pm 0.15$ at $94.8 \mathrm{~dB}$. Whilst, the lowest concentration reached $0.29 \pm 0.11$ at $92.5 \mathrm{~dB}$ compared to the control group $(0.17 \pm 0.04)$. This increase results from the malfunction that affects the liver and leads to a lack of the liver's ability to secrete bilirubin which clogs the bile ducts and the disease known as hepatic jaundice (Arjunan \& Rajan, 2020). 
Table 3

Impact of noise level and work-years on some of the biochemical variables

\begin{tabular}{lcccccc}
\hline & Parameter & $\begin{array}{c}\text { Noise level } \\
(94.8) \mathrm{dB}\end{array}$ & $\begin{array}{c}\text { Noise level } \\
(92.5) \mathrm{dB}\end{array}$ & $\begin{array}{c}\text { Working } \\
\text { years }(15)\end{array}$ & $\begin{array}{c}\text { Working } \\
\text { years }(10)\end{array}$ & Control \\
\hline T.P g/dl & Av \pm St error & $6.75 \pm 0.14$ & $6.43 \pm 0.46^{*}$ & $6.75 \pm 0.42$ & $6.44 \pm 0.22^{*}$ & $7.52 \pm 0.15^{*}$ \\
& Concentration\% & 89.76 & 85.50 & 89.76 & 85.63 & 100 \\
& Decrease \% & -10.24 & -14.5 & -10.24 & -14.37 & - \\
Urea mg/dl & Av \pm St error & $55.1 \pm 0.65 *$ & $39.5 \pm 0.06$ & $50.8 \pm 0.84$ & $41.0 \pm 0.34$ & $36.5 \pm 0.22^{*}$ \\
& Concentration\% & 150.95 & 108.21 & 139.17 & 112.32 & 100 \\
F.B.S mg/dl & Increase \% & 50.95 & 8.21 & 39.17 & 12.32 & - \\
& Av \pm St error & $72.3 \pm 6.7$ & $67.5 \pm 3.23$ & $86.52 \pm 10.1$ & $68.2 \pm 4.8$ & $59.62 \pm 18.7$ \\
& Concentration\% & 121.26 & 113.21 & 145.11 & 114.39 & 100 \\
Alb g/dl & Increase \% & 21.26 & 13.21 & 45.11 & 14.39 & - \\
& Av \pm St error & $4.37 \pm 0.17$ & $4.10 \pm 0.59$ & $4.35 \pm 0.48$ & $4.14 \pm 0.4$ & $4.00 \pm 0.9$ \\
& Concentration\% & 109.25 & 102.50 & 108.75 & 103.5 & 100 \\
Total & Increase \% & 9.25 & 2.50 & 8.75 & 3.5 & - \\
Cholesterol & Av \pm St error & 183.87 & 167.5 & 179.75 & 171.5 & 158.5 \\
mg/dl & & \pm 25.87 & \pm 23.1 & $\pm 24.16 *$ & $\pm 11.92^{*}$ & $\pm 0.64 *$ \\
& Concentration\% & 116 & 105.67 & 113.40 & 108.20 & 100 \\
\hline & Increase \% & 16 & 5.67 & 13.40 & 8.20 & - \\
\hline
\end{tabular}

\section{The Effect of Noise on the Functions of the Kidney}

Figure 3 indicates urine analysis for the operators, which shows different types of cells in the urine. The Pus cells revealed the highest percentage of $35 \%$ then, the RBCs were $30 \%$, the Epith cells were 20\%, and finally, the crystals were 15\%. Exposure to successive and high sounds leads to changes in the body systems. It affects the kidney structure, causing the penetration of proteins from blood to urine through the kidney's glomeruli. Consequently, this situation created signs of imbalance in the kidney's functionality lead to observing these different types of cells in the urine (Farong et al., 2018). However, causing much disorder

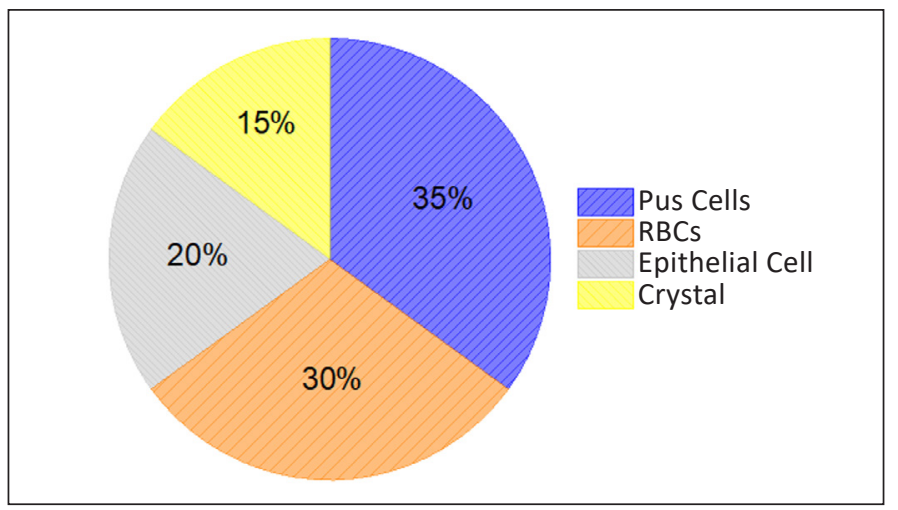

Figure 3. The percentage of various cells in the urine 
and abnormal impacts in the human body are related to this type of noise pollution, which is the response to the physiological damage-causing sediment of many kinds of stuff in the urinary tracts, thereby increasing the possibility of salt sediments in the urinary tracts especially in the case of ureter and bladder inflammation. The workers in such places do not have good personal hygiene habits and are not committed to stopping eating protein or meat. Also, the workers do not regularly visit doctors and medical centres.

\section{CONCLUSION}

Previously, it has not been directly addressed such this type of pollution caused by (random distributed backup electrical generators) in the Middle East. Therefore, this study can be considered the first to highlight such pollution, which can cause severe health conditions after long-term exposure. The exposure of these noise sources leads to significant differences in some blood parameters (Hb, RBCs, WBCs, PLT, PCV, TP, ALB, FBS, Bilirubin, Blood Urea, and Cholesterol. It was confirmed by comparing the control group results with those of the exposed group (workers). The noise intensity of the measured sites has reached 94.8 and $92.5 \mathrm{~dB}$. The first noise level, $94.8 \mathrm{~dB}$, showed a higher effect than the second level, $92.5 \mathrm{~dB}$. The operators exposed to the noise for 15 years are affected more than those with less exposure time (10 years). Therefore, it is recommended that workers take precautionary measures in the workplace (the backup electrical generators), including temporary work that involves various employment conditions, i.e. on-call and seasonal work.

\section{ACKNOWLEDGEMENTS}

The authors wish to express their gratitude to the College of Sciences at the University of Mosul for their unwavering support throughout this research project.

\section{REFERENCES}

Adimalla, N., Qian, H., Nandan, M. J., \& Hursthouse, A. S. (2020). Potentially toxic elements (PTEs) pollution in surface soils in a typical urban region of south India: An application of health risk assessment and distribution pattern. Ecotoxicology and Environmental Safety, 203(126), Article 111055. https://doi. org/10.1016/j.ecoenv.2020.111055

Allouche, L., Hamadouche, M., Touabti, A., \& Khennouf, S. (2011). Effect of long-term exposure to low or moderate lead concentrations on growth, lipid profile and liver function in albino rats. Advances in Biological Research, 5(6), 339-347.

Amoatey, P., Omidvarbona, H., Baawain, M. S., Al-Mayahi, A., Al-Mamun, A., \& Al-Harthy, I. (2020). Exposure assessment to road traffic noise levels and health effects in an arid urban area. Environmental Science and Pollution Research, 27(28), 35051-35064. https://doi.org/10.1007/s11356-020-09785-y 
Anetor, J. I., Yaqub, S. A., Anetor, G. O., Nsonwu, A. C., Adeniyi, F. A. A., \& Fukushima, S. (2009). Mixed chemical-induced oxidative stress in occupational exposure in Nigerians. African Journal of Biotechnology, 8(5), 821-826. https://doi.org/10.4314/ajb.v8i5.59972

Arjunan, A., \& Rajan, R. (2020). Noise and brain. Physiology and Behavior, 227(July), Article 113136. https:// doi.org/10.1016/j.physbeh.2020.113136

Arneson, W. L., \& Brickell, J. M. (2007). Clinical Chemistry: A laboratory perspective. F.A. Davis Company.

Ashmore, M. R., \& Dimitroulopoulou, C. (2009). Personal exposure of children to air pollution. Atmospheric Environment, 43(1), 128-141. https://doi.org/10.1016/j.atmosenv.2008.09.024

Asker, A. S., Tawfeeq, A. A., Alhamdani, H. A. A. A., \& Alhamdani, A. A. (2021). Effect of addition of ginger (Zingiber officinale) and vitamin $\mathrm{E}$ on level of cortisol, ADA enzyme and liver enzymes in Awassi ewes. IOP Conference Series: Earth and Environmental Science, 761(1), Article 012087. https://doi. org/10.1088/1755-1315/761/1/012087

Brink, M., Schäffer, B., Vienneau, D., Foraster, M., Pieren, R., Eze, I. C., Cajochen, C., Probst-Hensch, N., Röösli, M., \& Wunderli, J. M. (2019). A survey on exposure-response relationships for road, rail, and aircraft noise annoyance: Differences between continuous and intermittent noise. Environment International, 125(February), 277-290. https://doi.org/10.1016/j.envint.2019.01.043

Brook, R. D., \& Rajagopalan, S. (2009). Particulate matter, air pollution, and blood pressure. Journal of the American Society of Hypertension, 3(5), 332-350. https://doi.org/10.1016/j.jash.2009.08.005

Brunze, N. A. (2016). Fundamentals of urine and body fluid analysis-e-book (4th Ed.). Elsevier.

Cuesta, M., \& Cobo, P. (2000). Active control of the exhaust noise radiated by an enclosed generator. Applied Acoustics, 61(1), 83-94. https://doi.org/10.1016/S0003-682X(99)00062-6

Dongre, N. N., Suryakar, A. N., Patil, A. J., Ambekar, J. G., \& Rathi, D. B. (2011). Biochemical effects of lead exposure on systolic \& diastolic blood pressure, heme biosynthesis and hematological parameters in automobile workers of North Karnataka (India). Indian Journal of Clinical Biochemistry, 26(4), 400-406. https://doi.org/10.1007/s12291-011-0159-6

Dzhambov, A. M., \& Dimitrova, D. D. (2016). Exposure-response relationship between traffic noise and the risk of stroke : A systematic review with meta-analysis. Arhiv za higijenu rada i toksikologiju, 67(2), 136-151.

Dzhambov, A. M., \& Dimitrova, D. D. (2017). Crossmark. Environmental Research, 152(August 2016), 244255. https://doi.org/10.1016/j.envres.2016.10.024

Dzhambov, A. M., Dimitrova, D. D., \& Mihaylova-alakidi, V. K. (2016). Public health: Burden of sleep disturbance due to traffic noise in Bulgaria. Folia Medica, 57(3/4), 264-269. https://doi.org/10.1515/ folmed-2015-0049

Eduardo, P., Fiedler, K., Henrique, P., \& Zannin, T. (2015). Evaluation of noise pollution in urban traf fi c hubs - Noise maps and measurements. Environmental Impact Assessment Review, 51, 1-9. https://doi. org/10.1016/j.eiar.2014.09.014

Esch, T., Stefano, G. B., Fricchione, G. L., \& Benson, H. (2002). Stress in cardiovascular diseases. Medical Science Monitor, 8(5), RA93-RA101. 
Evandt, J., Oftedal, B., Krog, N. H., Skurtveit, S., Nafstad, P., Schwarze, P. E., Skovlund, E., Houthuijs, D., \& Aasvang, G. M. (2017). Road traffic noise and registry based use of sleep medication. Environmental Health, 16(1), 1-12. https://doi.org/10.1186/s12940-017-0330-5

Farong, Y., Xin, Y., Zuoping, L., Xiuzhen, L., Mingren, X., \& Denglou, L. (2018). Effects of noise pollution on functions of the liver and kidney of rats. Meteorological and Environmental Research, 9(4), 41-43. https://doi.org/10.19547/j.issn2152-3940.2018.04.010

Flies, E. J., Mavoa, S., Zosky, G. R., Mantzioris, E., Williams, C., Eri, R., Brook, B. W., \& Buettel, J. C. (2019). Urban-associated diseases: Candidate diseases, environmental risk factors, and a path forward. Environment International, 133(October), Article 105187. https://doi.org/10.1016/j.envint.2019.105187

Gori, T., Babisch, W., Basner, M., \& Mu, T. (2014). Cardiovascular effects of environmental noise exposure. European Heart Journal, 35(13), 829-836. https://doi.org/10.1093/eurheartj/ehu030

Hussien, B. M., Rabeea, M. A., \& Farhan, M. M. (2020). Characterization and behavior of hydrogen sulfide plumes released from active sulfide-tar springs, Hit-Iraq. Atmospheric Pollution Research, 11(5), 894-902. https://doi.org/10.1016/j.apr.2020.02.001

Ibhadode, O., Tenebe, I. T., Emenike, P. C., Adesina, O. S., Okougha, A. F., \& Aitanke, F. O. (2018). Assessment of noise-levels of generator-sets in seven cities of South-Southern Nigeria. African Journal of Science, Technology, Innovation and Development, 10(2), 125-135. https://doi.org/10.1080/20421338.2017.140 0711

Jadaan, K. S., Msallam, M., \& Abu-Shanab, D. A. (2016). The impact of road traffic noise on hospital workers. Indian Journal of Science and Technology, 9(1), 1-8. https://doi.org/10.17485/ijst/2016/v9i1/79259

Le, F., \& Hattingh, J. (1983). Comparative haematology of some South African birds. Comparative Biochemistry and Physiology - Part A: Physiology, 74(2), 443-448. https://doi.org/10.1016/0300-9629(83)90628-X

Maschke, C., Harder, J., Ising, H., Hecht, K., \& Thierfelder, W. (2002). Stress hormone changes in persons exposed to simulated night noise. Noise Health, 5(17), 35-45. https://doi.org/https://www.noiseandhealth. org/text.asp?2002/5/17/35/31836

Mohammed, M. I., Yousif, S. W., \& Rabeea, M. A. (2020). Physiological and biochemical changes analysis to labors blood samples in plastics recycling factory in Mosul-Iraq. Journal of Global Pharma Technology, 10(06), 281-288.

Oguntunde, P. E., Okagbue, H. I., Oguntunde, O. A., \& Odetunmibi, O. O. (2019). A study of noise pollution measurements and possible effects on public health in Ota Metropolis, Nigeria. Open Access Macedonian Journal of Medical Sciences, 7(8), 1391-1395. https://doi.org/10.3889/oamjms.2019.234

Oiamo, T. H., Luginaah, I. N., \& Baxter, J. (2015). Cumulative effects of noise and odour annoyances on environmental and health related quality of life. Social Science \& Medicine, 146, 191-203. https://doi. org/10.1016/j.socscimed.2015.10.043

Parvathi, K., \& Navaneetha Gopalakrishnan, A. (2003, December 15-17). Studies on control of noise from portable power generator. In Proceedings of the Third International Conference on Environment and Health, Chennai, India (pp. 328-338). Chennai, India. 
Paull, N., Krix, D., Torpy, F., \& Irga, P. (2020). Can Green Walls Reduce Outdoor Ambient Particulate Matter, Noise Pollution and Temperature? International Journal of Environmental Research and Public Health, 17(14), Article 5084. https://doi.org/10.3390/ijerph17145084

Richmond, W. (1973). Preparation and properties of a cholesterol oxidase from Nocardia sp. and its application to the enzymatic assay of total cholesterol in serum. Clinical Chemistry, 19(12), 1350-1356. https://doi. org/10.1093/clinchem/19.12.1350

Roswall, N., Raaschou-nielsen, O., Solvang, S., \& Tjønneland, A. (2018). Long-term exposure to residential railway and road tra ffi c noise and risk for diabetes in a Danish cohort. Environmental Research, 160(August 2017), 292-297. https://doi.org/10.1016/j.envres.2017.10.008

Sohrabi, S., \& Khreis, H. (2020). Burden of disease from transportation noise and motor vehicle crashes: Analysis of data from Houston, Texas. Environment International, 136(February), Article 105520. https:// doi.org/10.1016/j.envint.2020.105520

Sygna, K., Marit, G., Aamodt, G., Oftedal, B., \& Hjertager, N. (2014). Road traffic noise, sleep and mental health. Environmental Research, 131, 17-24. https://doi.org/10.1016/j.envres.2014.02.010

van Kempen, E., Casas, M., Pershagen, G., \& Foraster, M. (2018). WHO environmental noise guidelines for the European region: A systematic review on environmental noise and cardiovascular and metabolic effects : A summary. International Journal of Environmental Research and Public Health, 15(2), Article 379. https://doi.org/10.3390/ijerph15020379

Vladimir, M., \& Madalina, C. (2019). Optimizing urban landscapes in regard to noise pollution. Procedia Manufacturing, 32, 161-166. https://doi.org/10.1016/j.promfg.2019.02.197

WHO. (2011). Burden of disease from environmental noise. World Health Organization.

Xiao, J., Li, X., \& Zhang, Z. (2016). Daly-based health risk assessment of construction noise in Beijing, China. International Journal of Environmental Research and Public Health, 13(11), Article 1045. https://doi. org/10.3390/ijerph13111045

Yeatts, K., Svendsen, E., Creason, J., Alexis, N., Herbst, M., Scott, J., Kupper, L., Williams, R., Neas, L., Cascio, W., Devlin, R. B., \& Peden, D. B. (2007). Coarse particulate matter (PM2.5-10) affects heart rate variability, blood lipids, and circulating eosinophils in adults with asthma. Environmental Health Perspectives, 115(5), 709-714. https://doi.org/10.1289/ehp.9499 
